\title{
REVIEW
}

\section{THE PROCESS OF Leishmania INFECTION - DISEASE AND NEW PERSPECTIVES OF PALEOPARASITOLOGY}

\author{
Shênia Patrícia Corrêa NOVO(1), Daniela LELES(2), Raffaella BIANUCCI(3,4,5) \& Adauto ARAUJO(6)
}

\begin{abstract}
SUMMARY
Species of the genus Leishmania (Kinetoplastida, Trypanosomatidae) are causative agents of leishmaniasis, a complex disease with variable clinical spectrum and epidemiological diversity, constituting, in some countries, a serious public health problem. The origin and evolution of leishmaniasis has been under discussion regarding some clinical and parasitological aspects. After the introduction of paleoparasitology, molecular methods and immunodiagnostic techniques have been applied allowing the recovery of parasite remains, as well as the diagnosis of past infections in humans and other hosts. The dating of archaeological samples has allowed the parasitological analysis in time and space. This manuscript presents the state of the art of leishmaniasis and prospects related to paleoparasitology studies and their contribution to the evolutionary and phylogenetic clarification of parasites belonging to the genus Leishmania, and the leishmaniasis caused by them.
\end{abstract}

KEYWORDS: Leishmania; Paleoparasitology; Ancient DNA; Origin and evolution of diseases; Infection and disease in leishmaniasis.

\section{INTRODUCTION}

\section{Leishmaniasis at present}

Parasites of the genus Leishmania are obligatory intracellular protozoa belonging to the order Kinetoplastida, Trypanosomatidae family and are causative agents of leishmaniasis. The main feature of this order is the presence of a single branched mitochondria containing an extended region called kinetoplast. The kinetoplast, located near the basal body of the flagellum, has genetic material, the kDNA. This is an extra-nuclear circular DNA arranged in maxi and mini-circles, widely used in molecular analysis ${ }^{1}$. This parasite is transmitted through the bite of infected females sandflies (Diptera: Psychodidae, Phlebotominae), of the genus Phlebotomus (Loew, 1845) in the Old World, and Lutzomyia (France, 1924) in the Americas ${ }^{2}$.

The disease is manifested in the host in one of four forms: cutaneous disease with skin lesions, ulcerative or not, but limited; mucocutaneous disease that may evolve to destructive lesions of the mucous; cutaneous diffuse form of the disease that is spread on the skin and occurs in anergic individuals or late in patients that have been treated for visceral leishmaniasis or kala-azar, the form of disease in which the parasite has tropism for mononuclear phagocytic system cells of the spleen, liver, bone marrow and lymphoid tissues ${ }^{3}$.
There are several species of Leishmania and at least 13 are associated with human disease $\mathrm{e}^{4,5}$. According to the taxonomic classification of the species proposed by Lainson \& Shaw $(1987)^{6}$, that is currently the most used, the Leishmania species are divided into two subgenera: Leishmania and Viannia.

Data from the World Health Organization (2014) ${ }^{7}$, consider that leishmaniasis is present in 98 countries and three territories on five continents. About 1.3 million new cases occur annually, of which 300,000 cases are of visceral leishmaniasis, $90 \%$ of which occur in Bangladesh, Brazil, Ethiopia, India, Nepal and Sudan; and around 1,000,000 cases of cutaneous leishmaniasis occur mainly in Afghanistan, Algeria, Brazil, Colombia, the Islamic Republic of Iran, Pakistan, Peru, Saudi Arabia, Syrian Arab Republic and Tunisia; and mucocutaneous leishmaniasis occur mainly in Brazil, Peru and the Plurinational State of Bolivia. Unfortunately, of the 1.3 million estimated cases, only about 600,000 are officially reported ${ }^{7}$.

There are species whose presence are described only in reptiles, therefore they are classified in a separate genus called Sauroleishmania ${ }^{8,9}$. Sauroleishmania is considered an ancestor subgenus of the Leishmania genus $^{8}$. However, molecular analysis revealed the close relationship between these species and the ones that infect mammals ${ }^{10,11,12}$. This

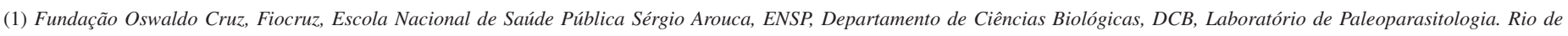
Janeiro, RJ, Brasil.E-mail: shenia@ensp.fiocruz.br

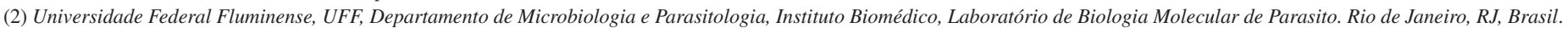
E-mail: dleles@id.uff.br

(3) Department of Public Health and Paediatric Sciences, Laboratory of Physical Anthropology, University of Turin. Italy.

(4) Center for Ecological and Evolutionary Synthesis (CEES), Department of Biosciences, University of Oslo. Oslo, Norway.

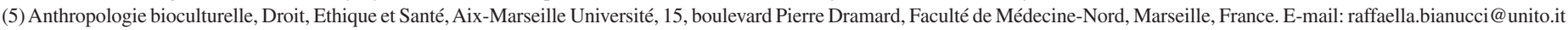

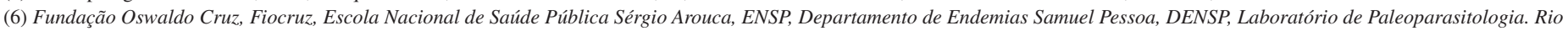
de Janeiro, RJ, Brasil. E-mail: adauto@ensp.fiocruz.br

Correspondence to: Shênia Patrícia Corrêa Novo. E-mail: shenia@ensp.fiocruz.br 
subgenus contains a species of considerable importance - Leishmania tarentolae.

Initially isolated in Tarentolae mauritanica ${ }^{13}$, a Moorish gecko, L. tarentolae species was also found in North Africa, France, Malta and Italy ${ }^{8,14,15,16,17}$. Pozio et al. $(1983)^{16}$ also found L. tarentolae in Cryptodactylus kotsehyi Steindacher (1870), in a small lizard cohabiting with T. mauritanica. Mohamed Elwasila ${ }^{18}$, in 1988, first described this Leishmania species in ancient lizards of the species Tarenrolae annularis recovered by Geoffroy in the year 1809, in Khartoum, Sudan.

In the Old World, after transmission to the reptile host by means of vector ingestion belonging to the genus Sergentomyia (France \& Parrot, 1920), the parasite seems to have gained access to the host circulation through the surfaces of the intestinal mucosa, possibly remaining in the reptile blood stream for all its life in the extracellular promastigote form ${ }^{12}$. Elwasila (1988) $)^{18}$, searching for natural infections in reptiles in Sudan, analyzed a total of 16 reptiles, detecting the presence of $L$. tarentolae, in the amastigote form, and three of them belonged to the species T. annularis. However, this form of Leishmania parasitemia was significantly low, and only 3 to 9 intracellular amastigotes could be found in a few leukocytes. Although not pathogenic to humans, L. tarentolae species has all the virulence genes found in the other species that are pathogenic to humans, with the exception of the A2 gene, responsible for the visceralization in species of the Leishmania donovani complex and also playing an important role in the transformation of promastigotes into amastigotes forms ${ }^{19}$. These forms can also be found in infected reptiles in which transmission is passive cutaneous $^{20,21}$. Nevertheless, Azizi et al. (2009) ${ }^{19}$ demonstrated that this gene does not have the same role in the non-pathogenic L. tarentolae. Thus, more studies are needed to clarify this issue. It is noteworthy that these genetic characteristics make the L. tarentolae species an important model to work on the development of vaccines ${ }^{22}$.

In the past, experimental studies were conducted in mammals, including a human volunteer who was inoculated with promastigote forms so as to observe the development of the parasite and possible emergence of pathogenicity in this volunteer. The results showed that L. tarentolae cycle did not develop in the human volunteer as it takes place with other Leishmania species, as there were no amastigote forms and no pathogeny ${ }^{23}$.

\section{Leishmaniasis in the Americas}

For a long time, the history of leishmaniasis has been studied, requiring further clarifications regarding the origin and the behavior of parasites responsible for this infection, as well as host-parasite relationships along time.

Rabello (1925) ${ }^{24}$ has suggested the existence of cutaneous leishmaniasis forms in the Americas for many years, and it was considered thereafter an indigenous disease in the Americas, long before the arrival of Europeans. Archaeological studies developed in so-called "Peruvian huacos" analyzed anthropomorphic ceramics constructed by Andean people who reproduced healthy human figures and disease-mutilated ones that could correspond to the occurrence of "uta" and "espundia", local names for cutaneous and mucous forms of cutaneous leishmaniasis, respectively, among the Incas in the pre-Columbian period ${ }^{25}$. However, the surest indication, and probably the oldest of the disease's existence in regions close to Brazil, was found in Tello's study (1908) "Antiguedad de la syphilis en el Peru", that describes the journey of missionary Frey Dom Hipolito Sanchez Rangel Fayas y Quiros, who toured in 1827 by the Amazonian region, crossing the Solimões-Amazonas river. According to these records, the mission had the opportunity to observe the existence of people with ulcers in legs and arms, related to insect bites, resulting in destructive lesions of the mouth and nose. On this occasion, Frey Hipolito affirmed: "[...] los mosquitos y demás insectos, son si no se tiene cuydado, um poderoso foment de llagas profundas y fétidas em piernas y brazos, hedor de boca, gallico [...]".

However, early reports of the disease in South America have been published by the Spanish Balthasar Ramirez in his book "Descripcion del Reyno del Peru" (1580), where the disease was called "Mal de los Andes". In the same period, Fray Rodrigo de Loayza (1586) noted the presence of nasal lesions not only in Indians but also in people entering the Andes region ${ }^{28}$. Sometime later, in 1884, in Italy, the dermatologist Achille Breda described the disease in 18 Italians from São Paulo State. Nevertheless, it was not possible to identify the nature of the parasite. Breda was the first to refer to the disease as "Bouba Brasiliana" and later, in 1910, the dermatologist Edouard Jeanselme considered that Breda was the first to describe the clinical aspects of the American cutaneous leishmaniasis in detail. For this reason, the disease became known by many researchers as "Breda Disease" 27 .

The Bahian physician Juliano Moreira, in the year 1894, presented at the meeting of the Society of Medicine and Surgery of Bahia, the study entitled: "Existe na Bahia o Botão de Birska?". In this study, Moreira meticulously described the clinical forms encountered and he named it Bahia Button. This was the first time that the existence of Birska button was demonstrated in Brazil. In addition, he reported the possibility of a transmitter insect of the disease. According to him: "À picada de um inseto, o muruim, tem sido muitas vezes attribuido por alguns doentes o início da affecção" 28 .

During the construction of the Railroad Northwest of Brazil, in 1908, numerous patients arrived from deforestation areas, especially from Bauru city in São Paulo State, so that the disease has become known as Bauru ulcer.

The discovery of the cutaneous leishmaniasis agent in mucosal lesions by Splendore $(1911)^{29}$ and the confirmation of the disease in several parts of the country, as in the Vale do Rio Doce, Minas Gerais, Amazonas and Southern Bahia, among others, represented the most proficient period with respect of the disease studies in Brazil.

Although he has had a short life, Gaspar Vianna was one of the most famous personalities in research related to leishmaniasis ${ }^{30}$. In 1911, he discovered a new species of the genus Leishmania, Leishmania braziliensis, now called L. (Viannia) braziliensi ${ }^{31}$. In the next year, Vianna developed a treatment for cutaneous leishmaniasis by using intravenous injections of tartar emetic ${ }^{32}$. This treatment is still used nowadays.

Aragão ${ }^{33}$, in 1922, demonstrated for the first time the role of cutaneous leishmaniasis transmission by sandfly bites in the Rio de Janeiro city, when analyzing the high density of the sandfly Lutzomyia intermedia, with the presence of infection in Águas Férreas city, in the Laranjeiras neighborhood. The confirmation of $L$. intermedia as a potential vector 
of $L$. (V.) braziliensis occurred after the onset of an ulcer in the nose of a dog, containing amastigotes after inoculation of a saline suspension containing $L$. intermedia previously fed with the patient's cutaneous leishmaniasis lesions.

In 1939-1940, the public health physician Samuel Barnsley Pessoa described the cutaneous leishmaniasis as an "occupational disease edge of the forest" and in 1941, it was estimated in more than 30,000 the number of patients only in rural areas, and these areas were considered highly endemic ${ }^{34}$.

The decades from 1950 to 1980 was a period characterized by the participation of Oswaldo Forattini in studies related to cutaneous leishmaniasis. In this research, Forattini was able to elucidate issues on transmission, the existence of natural Leishmania spp. reservoirs, describe the Phlebotominae family taxonomy, as well as aspects of the ecology and behavior of the vector species of this protozoan. Throughout the period, several infection outbreaks took place in some Brazilian states: São Paulo, Mato Grosso do Sul, Paraná, Rondônia and Amapá enabling pioneering discoveries on possible Leishmania animal reservoirs. The results of their research clarified the epidemiological transmission of cutaneous leishmaniasis and also the cycles that may have parasites in nature ${ }^{35}$.

Until the early 1960s, only to species of $L$. (V.) braziliensis were recognized to cause cutaneous leishmaniasis. Nevertheless, in 1961, Pessoa $^{36}$ proposed the subdivision of $L$. braziliensis in the varieties $L$. braziliensis, Leishmania guyanensis, Leishmania peruviana, Leishmania mexicana and Leishmania pifanoi, according to the differences in the clinical forms of the disease, in distinct geographical regions.

Since then, the classification of the parasite has been based on other criteria such as their behavior in culture, in experimental animals and their vectors, leading to the distinction between the mexican and the braziliensis complex ${ }^{37}$. Over time, the advances made by electron microscopy, molecular biology, biochemistry and immunology, have opened new perspectives in the taxonomy of these parasites, and have applied new methods for their characterization ${ }^{38}$.

Unlike cutaneous leishmaniasis, visceral leishmaniasis, known as Kala-azar (black fever), by the inhabitants of Assan, India, has symptoms that are similar to the ones of other tropical diseases ${ }^{1}$. Fever is one of the main symptoms, but there are no visible lesions, hindering the finding of ancient descriptions in the medical records.

Historical data are very important in helping the laboratory tests to detect Leishmania DNA in archaeological remains. Historical documents are essential since they can, in many cases, help to unveil the space-time of leishmaniasis. Furusawa \& Borges $(2014)^{39}$, for example, based on the analysis of postmortem inventories of slaves found in the Documentation Historical Center, demonstrated the possible existence of cutaneous leishmaniasis in the Vassouras city, Rio de Janeiro State, Brazil, in the early nineteenth century, before the period considered as the arrival of disease in Southeastern Brazil.

\section{Hypotheses for the origin of the genus Leishmania and subgenera Leishmania and Viannia}

Several possible origins of the genus Leishmania and subgenera
Leishmania and Viannia are proposed. Some authors suggest that the genus Leishmania has had its origin in the Neotropics (biogeographic region that includes Central America, from the southern part of Mexico and the peninsula below California, southern Florida, and all the Caribbean islands, to South America, while others have proposed the Palearctic, the zoogeographic region that includes Europe, North Africa, large part of Arabia and Asia to the north of the Himalayas, or the Nearctic (geographic region including the North America ${ }^{40,41,42}$. Through the use of molecular biology techniques Noyes et al. $(2000)^{43}$ obtained significant results that support the hypothesis of origin in the Neotropics. However, studies by Kerr et al. $(2000)^{40}$, based on the interpretation of molecular data supported by biochemical, molecular, biogeographic, ecological and entomological factors, proved that Leishmania has originated in the Palearctic. This hypothesis suggests that the genus Leishmania has entered the Nearctic across the Bering Strait during the Oligocene, rapidly dispersing during the Pliocene until reaching the Neotropics. Considering the genetic polymorphism and clonality of the genus Leishmania, parasites belonging to this genus may have made its way to the area where today the Americas are located, even before the separation of Gondwana, about a hundred million years $\mathrm{ago}^{40}$.

However, regardless of their origin, the spread of this parasite occurred together with the migration of their vectors and hosts ${ }^{25}$. The description of a new genus and species, Paleoleishmania proterus, found in remains of blood on the proboscis and digestive tract of a sandfly belonging to the Cretaceous period that was found in amber, shows that the parasite-vector relationship has existed since ancient times, suggesting that the definitive host of this parasite has been a reptile or a primitive mammal ${ }^{44}$.

Initially it was suggested that the subgenus Leishmania had appeared in the Paleocene, shortly after the extinction of dinosaurs and the emergence of the first placental mammals ${ }^{45}$. Currently, it is suggested that there has been a common ancestor of Leishmania which originated two distinct clades: the Sauroleishmania genus that infected reptiles, and Leishmania that currently infects mammals ${ }^{45}$.

Considering the subgenera L. (Leishmania) and L. (Viannia) and a possible origin in the Palearctic, the current distribution of species and their molecular trees, the subgenus L. (Leishmania) would have been the first to emerge. But there is controversy with respect to the origin of the subgenus L. (Viannia) ${ }^{9}$. Studies prove that this subgenus only occurs in the Neotropics, while the subgenus Leishmania occurs both in the New World (Neotropical regions and South Nearctic), as in the Old World (Palearctic regions, African and Eastern) ${ }^{46}$.

However, currently the most accepted theory is that the subgenus L. (Viannia) was originated after the separation of Gondwana and the subgenus L. (Leishmania) has its origin in the Palearctic, coming to the Americas by the Bering Strait ${ }^{40}$.

\section{Speculations about the origin of some Leishmania species and infection by Leishmania spp.}

Discussions are not restricted to the possible origin the genus and subgenera. Some authors suggest, for example, that in the Old World, species responsible for visceral leishmaniasis have been separated in $L$. 
donovani and Leishmania infantum about 1 million years $\mathrm{ago}^{40}$. This theory was also proposed by Mauricio et al. $(2007)^{47}$ based on analyzes of molecular trees of these species. The L. donovani species, therefore, appears to have originated in East Africa, the same region of the human origin.

For Leishmania (Leishmania) major, another species that causes cutaneous leishmaniasis in several regions of the world, it is suggested that its origin was in North Africa, where the Saharan region had humid climate and was covered by forest $\mathrm{t}^{47}$.

It is still unclear if humans have led the infection to the Middle East, or if it was acquired from other hosts. However, the sandfly vectors have existed long before the arrival of humans and other animals that today serve as hosts in Europe and Asia. It has also been suggested that the infection has originated in Central Asia in zoonotic reservoirs, dispersing to India, to the Mediterranean and to West Africa around the fourteenth century ${ }^{48}$.

Nevertheless, the dynamics of the population in South America between the Amazon and the inter-Andean regions was important to clarify the spread of infection and if this theory is confirmed, we will be able to say that the Andes would be the cradle of cutaneous leishmaniasis in the New World ${ }^{49}$.

Until now studies have failed to confirm the existence of visceral leishmaniasis before the arrival of Europeans to South America ${ }^{50}$. The studies of SHAW (2006) ${ }^{51}$ suggest that Leishmania (Leishmania) chagasi is originally from Europe and that it is very similar to the species $L$. $(L$.) infantum. Taxonomically $L$. (L.) infantum (synonym $L$. (L.) chagasi) belongs to the complex of species $L$. $(L$.) donovani. According to Abramson et al. $(1995)^{52}$, the formation of the isthmus between North America and South America may have occurred before the spread of Leishmania in the Amazon region and the Northeast of Brazil, a highly endemic area of $L$. (L.) chagasi. Thus, the idea that the species $L$. (L.) chagasi has been brought by the Europeans during the fifteenth century ${ }^{53,54}$ is reinforced. Another hypothesis is that this parasite has existed among indigenous of the Americas ${ }^{51,55,56,57,58,59}$.

\section{Direct evidence of DNA fragments of Leishmania spp. in archaeological remains by different techniques}

The Paleoparasitology provides new tools for the study of parasitic diseases, in which the host-parasite-environment complex cannot be separated, since it offers the only possibility of working with ancient parasites ${ }^{60}$ found in remnants of the human species and other animals recovered from archaeological sites, paleontological, or any other source that has maintained them preserved ${ }^{61}$. Thus, infections have been diagnosed with Leishmania spp. in ancient populations by the application of different techniques.

Poinar \& Poinar, in 2004, described a new genus and species of trypanosomatid (Paleoleishmania proterus) found in remains of blood on the proboscis and in the gastrointestinal tract of a sandfly found in amber from the Cretaceous period, by light microscopy. Therefore, they demonstrated that the parasite-vector relationship has existed since ancient times, suggesting that the definitive host of this parasite has been a reptile or a primitive mammal ${ }^{44}$.
In certain high altitude areas, as in the Atacama Desert, Chile, where the disease is not normally found, the presence of these parasites suggests a pattern of mobility in endemic areas ${ }^{62,63}$ dating from 1,000 BC. This has been discussed in studies by Costa et al. (2009) ${ }^{62}$ who identified bone disfiguring facial injuries with leishmaniasis characteristics in four women who died in a community located in a high altitude desert where there was no leishmaniasis. To confirm the etiology of injuries, authors have used molecular methods that have identified Leishmania DNA in three of the individuals analyzed.

Zink et al. (2006) ${ }^{64}$ used molecular techniques, mitochondrial DNA (mtDNA) to detect Leishmania DNA in samples of more than 90 mummies originated from the pre-Egyptian Abydos Dynasty (3,5002,800 BC) and the Western Empire (2,050-1,650 BC). The analysis of parasite DNA found in 13 of these mummies was consistent with the DNA of Leishmania (Leishmania) donovani, suggesting the visceral form of infection.

Nerlich et al. (2012) ${ }^{65}$ and Bianucci et al. $(2012)^{66}$ used molecular and immunodiagnostic tests to detect the presence of $L$. $(L$.) infantum in bone fragments of Eleonora from Toledo $(1,522-1,562)$, wife of Cosimo I de' Medici and member of one of the major political Italian families during the Renaissance. The positive identification of Leishmania infection in bone samples was obtained using two independent approaches. The first one was the molecular analysis of ancient DNA (aDNA) by the amplification of a specific fragment of $123 \mathrm{bp}$ (base pairs) from a conserved region of the mini-circle molecule of the Leishmania kinetoplastid mitochondrial DNA (kDNA) ${ }^{67,68}$ and the results were compatible with $L$. $(L)$. infantum. This result is achieved through the technique of Polymerase Chain Reaction (PCR) that was replicated in two independent laboratories. The second approach was a protein assay that showed a positive reaction, i.e., recognized a $L$. infantum protein, and at the same time IgG against $L$. infantum was detected by a Western blot technique.

Guillen \& Allison $(2005)^{49}$, examining a peruvian mummy of a six years old girl, dated $800 \mathrm{BC}$, observed the presence of macrophages containing Leishmania as revealed by immune-histological examination.

As noted, the different methodologies used have been productive, providing considerable information that helps us in paleoparasitological studies of this protozoan. Small aDNA fragments detected in tissues and bones of mummies, as well as immunodiagnostic techniques used to assist molecular methods have shown that infection by this parasite were present in mummies from different regions and different periods, clarifying questions about the host-parasite relationship and providing evidence for the studies of evolution and phylogeny of these parasites.

\section{Leishmania - infection and disease}

Parasitic infections and parasitic diseases are two distinct situations originated from a single process. The parasite is a necessary condition but not sufficient to start a parasitic disease ${ }^{69}$. The parasitic disease results from the presence of a certain parasite in a certain host, in a given population, in a given environment, and over a period of particular life coevolution of both protagonists ${ }^{69}$.

The first attempts to classify clinical forms of leishmaniasis 
date from the early twentieth century. The different clinical forms in patients affected by cutaneous leishmaniasis induce many specialists to an erroneous diagnosis ${ }^{70}$. One of the forms resembles very much the manifestations of hanseniasis; at that time called leprosy. The first atypical and rare cases, one in Brazil, one in Bolivia and two in Venezuela presented maculo-papular and nodular lesions and the spread of the disease, its chronicity and resistance to treatment, the wealth of parasites in the lesions and the great similarity with leprosy led this clinical manifestation of leishmaniasis to be called "lepromatoid form" ${ }^{71,72}$. Destombs ${ }^{73}$, in 1960, comparing leishmaniasis with the polar forms of leprosy, considered the primary diffuse cutaneous and the cutaneous forms of leishmaniasis as the benign and malignant poles of the disease. In 1970, Padilha-Gonçalves ${ }^{74}$ described the concept of cutaneous leishmaniasis polarity, considering the cutaneous form as the benign pole, the primary diffuse cutaneous as the malignant pole and the mucosa as part of the spectrum border. Thus, Padilha-Gonçalves referred to an immune-resistant pole and immunosuppressed pole ${ }^{74}$.

The historic and classical classification of leishmaniasis is: visceral (Kalazar) produced by the L. donovani species (Laveran and Mesnil, 1903), cutaneous (the Orient Button) produced by Leishmania tropica (Wright, 1903) and mucocutaneous form (cutaneous) produced by $L$. braziliensis (Gaspar Vianna, 1911). However, this classification was made exclusively by observing the clinical and evolutionary behavior of the disease $\mathrm{e}^{75}$. However, according to Azulay (1977) ${ }^{76}$ who had already found clinical and immune-pathological differences among leishmaniasis infections, he related the differences to defensive reactions of the human organism. Most of the times, the clinical descriptions of American cutaneous leishmaniasis (ACL) were attributed to infections by $L$. braziliensis ${ }^{31}$; nevertheless clinical characteristics of infections by different species of Leishmania have been demonstrated, leding to the proposal of various classifications ${ }^{77,78,79}$. In addition, there is a close relationship among the occurrence of different clinical forms of the disease and factors related to species and parasite strains, vector habits, factors related to the host immune response and to the hostparasite interaction. Regional differences have also been observed in the occurrence of geographical areas of disease $e^{6,38,80}$.

Considering the original description of species and proposed classifications based on extrinsic criteria and on results obtained by biochemical and molecular methods, it is currently accepted that there are several Leishmania species, of which more than 20 are associated with human disease in the Old and the New World ${ }^{7}$.

Regardless of the limitations of molecular paleoparasitology studies in which only small fragments can be analyzed, molecular techniques have recently provided the first evidence of aDNA sequences of $L$. tarentolae species found in the bone marrow and the intestines of an adult male mummy, coming from the Itacambira's municipality, Minas Gerais State, Brazil, dated from the colonial period. Although, more studies are needed in an attempt to recover $L$. tarentolae DNA from other regions so as to prove that the infection in the mummy was not an isolated finding, this result at least opens up some prospects for the understanding of the health-disease process. This finding reopens the debate about the potential existence of a $L$. tarentolae strain in human macrophages, as well as its capacity to systematically disseminate ${ }^{81}$. Nevertheless, as has been discussed in the case of sauroleishmanias, until the moment, no pathogenic effect caused by L. tarentolae has been proved in humans.
The finding of this Leishmania species in the Brazilian mummy raises an important question that could be related to epidemiological investigations performed in endemic areas in which positive serological results were found, but there was no evidence of injury. A similar situation was demonstrated by Marzochi et al. $(1980)^{82}$, after analyzing the frequency of antibody titers through an indirect immunofluorescence test and the Montenegro test in 47 individuals in Jacarepagua neighborhood, Rio de Janeiro State, Brazil suspected of having for American cutaneous leishmaniasis. The study found positive antibody titers in $57.2 \%$ of individuals without lesions or scars, examined in 1974 and reexamined in 1978. This discordance between the serological results and clinical manifestations had already been demonstrated by Pessoa \& Barreto $(1948)^{26}$ in the Brazilian territory and by Aston \& Thorley $(1970)^{84}$, analyzing Montenegro test results performed among Amerindians of the Xingu National Park region.

Would those be cases of Leishmania infection without illness? However, the detection of a DNA fragment compatible with L. tarentolae in a human host, although mummified and dated of 300 years ago, brings the possibility of infection by closely related species incapable of causing injury, but with the potential to stimulate the host defense and immunity.

Unfortunately, questions related to parasites of the genus Leishmania still remain, especially regarding the origin of these parasites. The paleoparasitology can clarify events that took place in ancient times among the species of Leishmania and their hosts, contributing to the understanding of the origin and evolution of the parasite ${ }^{84}$. Although the immunodiagnostic techniques continue to be applied in paleoparasitologic studies for the diagnosis of Leishmania spp. ${ }^{66}$, the emergence of molecular techniques that have higher sensitivities have significantly opened this field of study. The technical adaptation of PCR to detect aDNA made the diagnosis of various infections in prehistoric populations possible. However, there is always the need to develop new methods and procedures adjustments according to the process and the status of preservation of the archaeological material ${ }^{85,86,87}$.

The paleoparasitological steps are promising to clarify the gaps that still exist in relation to leishmanias. The most encouraging is that there are many possibilities for the paleoparasitology research that could bring new data on the antiquity and developmental stages of the host-parasite relationship, and also epidemiological data which could suggest strategies applicable today.

\section{REFERENCES}

1. Rey L. Parasitologia. 4a ed. Rio de Janeiro: Guanabara Koogan; 2008.

2. Brasil. Ministério da Saúde. Secretaria de Vigilância em Saúde. Manual de vigilância e controle da leishmaníase tegumentar americana. Brasília: Ministério da Saúde; 2007.

3. Coura JR. Dinâmica das doenças infecciosas e parasitárias. Rio de Janeiro: Guanabara Koogan; 2005.

4. Grimaldi G Jr, Tesh RB, McMahon-Pratt D. A review of the geographic distribution and epidemiology of leishmaniasis in the New World. Am J Trop Med Hyg. 1989;41: $687-725$.

5. Lainson R. The American leishmaniasis: some observations on their ecology and epidemiology. Trans R Soc Trop Med Hyg. 1983;77:569-96. 
6. Lainson R, Shaw JJ. Evolution, classification and geographical distribution. In: Peters W, Killick-Kendric K, editors. The leishmaniases in biology and medicine. London: Academic Press; 1987. p. 1-120.

7. World Health Organization. Leishmaniasis: 09 December 2014. Geneva: WHO; 2014. Available from: http://www.who.int/mediacentre/factsheets/fs375/en/.

8. Laveran A, Franchini G. Des hematozoaires du gecko et specialement de Herpetomonas tarentolae. Procédé simple de culture des Herpetomonas. Bull Soc Pathol Exot. 1921;14:323-6.

9. Tuon FF, Amato Neto V, Amato SV. Leishmania: origin, evolution and future since the Precambrian. FEMS Immunol Med Microbiol. 2008;54:158-66.

10. Briones MRS, Nelson K, Beverley SM, Affonso HT, Camargo EP, Floeter-Winter LM. Leishmania tarentolae taxonomic relatedness inferred from phylogenetic analysis of the small subunit ribosomal RNA gene. Mol Biochem Parasitol. 1992;53:121-8.

11. Fu G, Kolesnikov AA. Leishmania gymnodactyli and Leishmania infantum minicircles contain the same guide RNA genes as do minicircles of Leishmania tarentolae. Mol Biochem Parasitol. 1994;67:171-4.

12. Wenyon DM. Observations on the intestinal protozoa of three Egyptian lizards, with a note on a cell-invading fungus. Parasitology. 1920;12:350-65.

13. Chatton E, Blanc G. Existence de corps leishmaniformes dans les hématoblastes d'un gecko barbaresque Tarentola mauritanica L Gunth. C R Soc Biol. 1914;77:430-3.

14. Adler S, Theodor O. Investigation of Mediterranean Kala Azar: X. A note on Trypanosoma platydactyli and Leishmania tarentolae. Proc R Soc Lond B Biol Sci. 1931;116:543-4.

15. Parrot L, Foley H. Sur la fréquence de la leishmaníase du gecko dans le sud oranais. Arch Inst Pasteur Alger. 1939;17:231-2.

16. Pozio E, Gramiccia M, Gradoni L, Maroli M. Hemoflagellates in Cyrtodactylus kotschyi (Steindachner 1870) (Reptilia, Geckkonidae) in Italy. Acta Trop. 1983;40: 399-400.

17. Rioux JA, Knoepfler LP, Martini A. Presence en France de Leishmania tarentolae Wenyon, 1921 parasite du gecko Tarentola mauritanica. Ann Parasitol Hum Comp. $1969 ; 44: 115-6$

18. Elwasila M. Leishmania tarentolae Wenyon, 1921 from the gecko Tarentola annularis in the Sudan. Parasitol Res. 1988;74:591-2.

19. Azizi H, Hassani K, Taslimi Y, Shateri Najafabadi H, Papadopoulou B, Rafati S. Searching for virulence factors in the non-pathogenic parasite to humans Leishmania tarentolae. Parasitology. 2009;136:723-35.

20. Paperna I, Boulard Y, Hering-Hagenback SH, Landau I. Description and ultrastructure of Leishmania zuckermani n. sp. amastigotes detected within the erythrocytes of the South African gecko Pachydactylus turneri Gray, 1864. Parasite. 2001;8:349-53.

21. Raymond F, Boisvert S, Roy G, Ritt J, Légaré D, Isnard A, et al. Genome sequencing of the lizard parasite Leishmania tarentolae reveals loss of genes associated to the intracellular stage of human pathogenic species. Nucleic Acids Res. 2012;40: 113147.

22. Breton M, Tremblay MJ, Ouellette M, Papadopoulou B. Live nonpathogenic parasitic vector as a candidate vaccine against visceral leishmaniasis. Infect Immun. 2005;73:6372-82.

23. Krjukova AP. Experimental cutaneous leishmaniasis of wild rodents of Turkmenia. In: Problemy kozhnogo leishmanioza. Ashkhabad: Turkmengosizdat; 1941. p. 241-8. Apud Wilson V, Southgate B. Lizard Leishmania. In: Lumsden W, Evans D, editors. Biology of Kinetoplastida. New York: Academic Press; 1979. p. 242-68.
24. Rabello E. Contribuição ao estudo da leishmaníase tegumentar no Brasil. I. História e synonímia. An Bras Derm Sifilogr. 1925;1:3-29.

25. Perrotey S, Mahamdallie SS, Pesson B, Richardson KJ, Gallego M, Ready PD Postglacial dispersal of Phlebotomus perniciosus into France. Parasite. 2005; 12:28391.

26. Pessoa SB, Barreto MP. Leishmaníase tegumentar americana. Rio de Janeiro: Ministério da Educação e Saúde, Imprensa Nacional; 1948.

27. Pampligione S. Contribution of Achille Breda to the understanding of American mucocutaneous leishmaniasis. Parassitologia. 1979;21:35-58.

28. Moreira J. Existe na Bahia o botão de Biskra?. Gaz Méd Bahia. 1895;254-8.

29. Splendore A. Buba-blastomicosi-leishmanosi. Nota sopra alcune affezion framboesiche osservate in Brasile. Arch für Schiffs-und Tropenhyg. 1911;15:105-15.

30. Deane LM. Sobre Gaspar Vianna, no centenário de seu nascimento. Mem Inst Oswaldo Cruz. 1985 80:122-24.

31. Vianna G. Sobre uma nova espécie de Leishmania. Bras Méd. 1911;25:411-2.

32. Vianna G. Tratamento da leishmaníase tegumentar por injeções intravenosas de tártaro emético. Arq Bras Med. 1912;4:426-8.

33. Aragão HB. Transmissão da leishmaníase no Brasil pelo Phlebotomus intermedius Bras Méd. 1922;36:129-30

34. Magalhães P. Normas e diretrizes para controle da leishmaníase cutâneo-mucosa (Tegumentar americana). In: Prata A, editor. Situação e perspectiva do controle das doenças infecciosas e parasitárias. Brasília: Ed. Universidade de Brasília; 1981. p.153-8.

35. Sallum MAM, Barata JMS, Santos RLC. Oswaldo Paulo Forattini: epidemiologista entomologista e humanista. Rev Saude Publica. 2007;41:885-90.

36. Pessoa SB. Classificação das leishmaníases e das espécies do gênero Leishmania Arq Fac Hig Sao Paulo. 1961;26:41-50.

37. Lainson R, Shaw JJ. Leishmaniasis of the New World: taxonomic problems. Br Med Bull. 1972;28:44-8.

38. Shaw JJ. Taxonomia do gênero Leishmania: onceito tradicionalista $\mathrm{x}$ conceito moderno. An Bras Dermatol. 1985;60:67-72.

39. Furusawa GP, Borges MF. Colaboração para o conhecimento do histórico da leishmaníase tegumentar americana no Brasil: possíveis casos entre escravos da vila de Vassouras-RJ, nos anos 1820 a 1880. Rev Patol Trop. 2014;43:7-26.

40. Kerr SF, Merkelz R, Mackinnon C. Further support for a Palaearctic origin of Leishmania. Mem Inst Oswaldo Cruz. 2000;95:579-81.

41. Lukes J, Mauricio IL, Schönian G, Dujardin JC, Soteriadou K, Dedet JP, et al Evolutionary and geographical history of the Leishmania donovani complex with a revision of current taxonomy. Proc Natl Acad Sci USA. 2007;104:9375-80.

42. Noyes H. Implications of a Neotropical origin of the genus Leishmania. Mem Ins Oswaldo Cruz. 1998;93:657-62.

43. Noyes HA, Morrison DA, Chance ML, Ellis JT. Evidence for a Neotropical origin of Leishmania. Mem Inst Oswaldo Cruz. 2000;95:575-8.

44. Poinar G Jr, Poinar R. Paleoleishmania proterus n. gen., n. sp., (Trypanosomatidae: Kinetoplastida) from Cretaceous Burmese amber. Protist. 2004;155:305-10.

45. Momen H, Cupolillo E. Speculations on the origin and evolution of the genus Leishmania. Mem Inst Oswaldo Cruz. 2000;95:583-8. 
46. Thomaz-Soccol V, Lanotte G, Rioux JA, Pratlong F, Martini-Dumas A, Serres E Monophyletic origin of the genus Leishmania Ross, 1903. Ann Parasitol Hum Comp. 1993;68:107-8.

47. Mauricio IL, Gaunt MW, Stothard JR, Miles MA. Glycoprotein 63 (gp63) genes show gene conversion and reveal the evolution of Old World Leishmania. Int J Parasitol. 2007;37:565-76

48. Oumeish OY. Cutaneous leishmaniasis: a historical perspective. Clin Dermatol 1999; 17:249-54

49. Guillen S, Allison M. An early case of South American Leishmaniasis in Peru. In: 1st Paleopathology Association Meeting in South America. Rio de Janeiro; 2005. p.62

50. Momen H, Pacheco RS, Cupolillo E, Grimaldi G Jr. Molecular evidence for the importation of Old World Leishmania into the Americas. Biol Res. 1993;26:249-55.

51. Shaw JJ. Further thoughts on the use of the name Leishmania (Leishmania) infantum chagasi for the aetiological agent of American visceral leishmaniasis. Mem Inst Oswaldo Cruz. 2006;101:577-9.

52. Abramson MA, Dietze R, Frucht DM, Schwantz R, Kenney RT. Comparison of New and Old World leishmaniasis in an endemic region of Brazil. Clin Infect Dis. 1995;20:1292-7.

53. Kuhls K, Alam MZ, Cupolillo E, Ferreira GEM, Mauricio IL, Oddone R, et al. Comparative microsatellite typing of new world Leishmania infantum reveals low heterogeneity among populations and its recent old world origin. PLoS Negl Trop Dis. 2011;5:1-16.

54. Leblois R, Kuhls K, François O, Schönian G, Wirth T. Guns, germs and dogs: on the origem of Leishmania chagasi. Infect Genet Evol. 2011;11:1091-5.

55. Killick-Kendrick R, Molyneux DH, Rioux JA, Lanotte G, Leaney AJ. Possible origins of Leishmania chagasi. Ann Trop Med Parasitol. 2006;74:563-5.

56. Lopes da Silva MA, Medeiros RA, Brandão-Filho S, Melo FL, Medeiros Z. Alvos moleculares utilizados em PCR para o diagnóstico da Leishmaníase visceral humana. Rev Eletron Farm. 2010;7:1-15.

57. Momen H, Grimaldi G Jr, Deane LM. Leishmania infantum, the aetiological agent of American visceral leishmaniasis (AVL)?. Mem Inst Oswaldo Cruz. 1987;82:447-8.

58. Shaw JJ. Taxonomy of the genus Leishmania: present and future trends and their implications. Mem Inst Oswaldo Cruz. 1994; 89:471-8.

59. Shaw JJ. New World leishmaniasis: the ecology of Leishmaniasis and the diversity of leishmanial species in Central and South America. In: Farrel J, ed. World class parasites: Leishmania. Boston: Kluwer Acad Publ; 2002. p. 11-31.

60. Araújo A, Jansen AM, Bouchet F, Reinhard K, Ferreira LF. Parasitism, the diversity of life, and paleoparasitology. Mem Inst Oswaldo Cruz. 2003;98 Suppl 1:5-11.

61. Ferreira LF, Reinhard KJ, Araújo, A. Origem dos parasitos humanos. In: Ferreira LF, Reinhard K, Araújo A, editores. Fundamentos da paleoparasitologia. Rio de Janeiro: Ed. Fiocruz; 2011. p.121-39.

62. Costa MA, Matheson C, Iachetta L, Llagostera A, Appenzeller O. Ancient leishmaniasis in a highland desert of northern Chile. PLoS ONE. 2009;4:e6983.

63. Marsteller SJ, Torres-Rouff C, Knudson KJ. Pre-Columbian Andean sickness ideology and the social experience of leishmaniasis: a contextualized analysis of bioarchaeological and paleopathological data from San Pedro de Atacama, Chile. Int J Paleopathol. 2011;1:24-34.

64. Zink AR, Spigelman M, Schraut B, Greenblatt CL, Nerlich AG, Donoghue HD. Leishmaniasis in ancient Egypt and Upper Nubia. Emerg Infect Disease. 2006;12:1616-7.
65. Nerlich AG, Bianucci R, Trisciuoglio A, Schönian G, Ball M, Giuffra V, et al. Visceral leishmaniasis during Italian renaissance, 1522-1562. Emerg Infect Dis. 2012;18:1846.

66. Bianucci R, Giuffra V, Bachmeier BE, Ball M, Pusch CM, Fornaciari G, et al. Eleonora of Toledo (1522-1562): evidence for tuberculosis and leishmaniasis co-infection in Renaissance Italy. Int J Paleopathol. 2012;2:231-5.

67. Degrave W, Fernandes O, Campbell D, Bozza M, Lopes U. Use of molecular probes and PCR for detection and typing of Leishmania: a mini-review. Mem Inst Oswaldo Cruz. 1994;89:463-9.

68. Rodgers MR, Popper SJ, Wirth DF. Amplification of kinetoplast DNA as a tool in the detection and diagnosis of Leishmania. Exp Parasitol. 1990;71:267-75.

69. Ferreira LF. O fenômeno parasitismo. Rev Soc Bras Med Trop. 1973;4:261-77.

70. Nery-Guimarães F. Estado atual dos conhecimentos da "forma lepromatóide" da leishmaniose tegumentar (LT). Hospital. 1965;67(1):58-92.

71. Nery-Guimarães F. Leishmaniose experimental. IV. Reprodução e, hamsters (Cricetus auratus) de uma leishmaniose cutânea nódulo-tumoral oriunda da Amazônia (Histiocitoma leushmaniótico). Hospital. 1951b;40(5):665-77.

72. Nery-Guimarães F. Leishmaniose experimental. V. Reprodução em camundongos (Mus musculi, var. albina) de uma leishmaniose cutânea nódulo-tumoral (Histiocitoma leishmaniótico) ocorrendo na Amazônia. Hospital. 1951c;40(6):919-34.

73. Destombes P. Application du concept de "sustématization polaire" aux leishmanioses cutanées. Bull Soc Pathol Exot. 1960;53:299-301.

74. Padilha-Gonçalves A, Guimarães NA. Leishmaniosis. In: I Reunión Conjunct $6^{\text {a }}$ de la Canadian Dermatological Association y la Academia Mexicana de Dermatologia y la III Reunión México-Centro-Americana de Dermatologia. México;1970.

75. Furtado TA. Leishmaniose tegumentar americana. In: Machado-Pinto J, editor. Doenças infecciosas com manifestações dermatológicas. Rio de Janeiro: Ed. Medsi; 1994. p. $319-36$

76. Azulay RD. Classificação clinic-imuno-patológica da leishmaniose. An Bras Dermatol. 1977;52:345-52

77. Azulay RD, Azulay DR Jr. Immune-Clinical-Pathologic spectrum of leishmaniasis. Int J Dermatol. 1995;34:303-7.

78. Marzochi MCA. Leishmanioses no Brasil: as leishmanioses tegumentares. J Bras Med. 1992;63:82-104.

79. Oliveira-Neto MP, Mattos M, Souza CS, Fernandes O, Pirmez C. Leishmaniasis recidiva cutis in New World cutaneous leishmaniasis. Int J Dermatol. 1998;37:846-9.

80. Ferroglio E, Centaro E, Mignone W, Trisciuoglio A. Evaluation of an ELISA rapid device for the serological diagnosis of Leishmania infantum infection in dog as compared with immunofluorescence assay and Western blot. Vet Parasitol. 2007;144: $162-6$

81. Novo SPC, Leles D, Bianucci R, Araújo A. Leishmania tarentolae molecular signatures in a 300 hundred-years-old human Brazilian mummy. Parasit Vectors. 2015;8:72.

82. Marzochi MCA, Coutinho SG, Sabroza PC, de Souza WJS. Reação de imunofluorescência indireta e intradermorreação para leishmaniose tegumentar americana em moradores na área de Jacarepaguá (Rio de Janeiro). Estudo comparativo dos resultados observados em 1974 e 1978. Rev Inst Med Trop Sao Paulo. 1980;22:149-55.

83. Aston DL, Thorley AP. Leishmaniasis in Central Brazil: results of a Montenegro skin-test survey among Amerindians in Xingu National Park. Trans R Soc Trop Med Hyg. 1970;64:671-8. 
84. Araújo A, Ferreira LF. Paleoparasitology and the antiquity of human host-parasite relationships. Mem Inst Oswaldo Cruz. 2000;95 Suppl 1:89-93.

85. Araújo A, Reinhard K, Bastos OM, Costa LC, Pirmez C, Iñiguez A, et al. Paleoparasitology: perspectives with new techniques. Rev Inst Med Trop Sao Paulo. 1998;40:371-6.
86. Orlando L, Hänni C. Du nouveau pour l'ADN ancien. Soc Franc Gen. 2000;16:8-9.

87. Rollo F, Marota I. How microbial ancient DNA, found in association with human remains, can be interpreted. Phil. Trans R Soc B Biol Sci. 1999;354:111-9.

Received: 15 May 2015

Accepted: 16 November 2015 